\title{
ОЦІНКА ЕКОЛОГІЧНОГО ВПЛИВУ ПРИ ПРОВЕДЕННІ РОБІТ З БЛАГОУСТРОЮ ПРИБУДИНКОВИХ ТЕРИТОРІЙ
}

\section{Г. М. Желновач}

Харківський національний автомобільно-дорожній університет

вул. Ярослава Мудрого, 25, м. Харків, 61002, Україна. E-mail: zhelnovach84@ gmail.com

Визначено джерела та наслідки екологічного впливу при проведенні робіт з благоустрою прибудинкових територій. Встановлено, що максимальний вплив спричиняється на атмосферне повітря при роботі дорожньобудівельних машин. Проведений розрахунок забруднення атмосферного повітря при проведенні робіт з благоустрою прибудинкової території для типового об'єкту дозволив встановити суттєве перевищення нормативних вимог щодо якості атмосферного повітря населених пунктів за всіма забруднюючими речовинами на визначених відстанях, що свідчить про значний рівень екодеструктивного впливу проведення таких робіт. Запропоновано природоохоронні рекомендації для зменшення подібного впливу, які стосуються контролю за димністю дизельних двигунів, зменшення іiі рівня застосуванням протидимних присадок, а також проведення контролю екологічних характеристик дорожньо-будівельних машин на етапі їх експлуатації.

Ключові слова: екологічний вплив, атмосферне повітря, урбанізована територія, благоустрій, прибудинкова територія, дорожньо-будівельні машини.

\section{ОЦЕНКА ЭКОЛОГИЧЕСКОГО ВОЗДЕЙСТВИЯ РАБОТ ПО БЛАГОУСТРОЙСТВУ ПРИДОМОВЫХ ТЕРРИТОРИЙ}

\section{А. Н. Желновач}

Харьковский национальный автомобильно-дорожный университет

ул. Ярослава Мудрого, 25, г. Харьков, 61002, Украина. E-mail: zhelnovach84@gmail.com

Определены источники и последствия экологического воздействия при проведении работ по благоустройству придомовых территорий. Установлено, что максимальное влияние вызывается на атмосферный воздух при работе дорожно-строительных машин. Проведенный расчет загрязнения атмосферного воздуха при проведении работ по благоустройству придомовой территории для типового объекта позволил установить существенное превышение нормативных требований к качеству атмосферного воздуха населенных пунктов по всем загрязняющими веществами на заданных расстояниях, что свидетельствует о значительном уровне экодеструктивного влияния проведения таких работ. Предложены природоохранные рекомендации для уменьшения подобного влияния, касающихся контроля за дымностью дизельных двигателей, уменьшение ее уровня применением противодымных присадок, а также проведения контроля экологических характеристик дорожно-строительных машин на этапе их эксплуатации.

Ключевые слова: экологическое воздействие, атмосферный воздух, урбанизированная территория, благоустройство, придомовая территория, дорожно-строительные машины.

АКТУАЛЬНІСТЬ РОБОТИ. Забруднення атмосферного повітря в умовах урбанізованих територій $\epsilon$ однією з найбільш актуальних проблем сучасності. Для великих населених пунктів характерний пріоритетний вплив пересувних джерел забруднення, першочергово з яких розглядають вплив руху автомобільного транспорту на якість повітря $[1,2]$. Вважаємо за доцільне зауважити, що при цьому не приймаються до уваги інші процеси, які призводять до погіршення якості атмосфери. До таких процесів, зокрема, слід віднести процеси благоустрою прибудинкових територій, а саме роботу дорожньобудівельної техніки на територіях та об'єктах безпосередньо наближених до житлових будівель, закладів освіти, лікарень тощо. Окрім того, така діяльність не підпадає під перелік робіт, які вимагають обов'язкового екологічного обгрунтування [3], тому неможливо виявити ступінь такого впливу на формування якості атмосферного повітря, що є особливо актуальним в умовах житлової забудови.

До основних задач роботи можна віднести наступні:

- визначення джерел та наслідків екологічного впливу при проведення робіт з благоустрою прибудинкових територій;

- оцінка забруднення атмосферного повітря при проведенні робіт з благоустрою прибудинкової території об’єкту дослідження;

- розробка природоохоронних рекомендації.

Метою даної роботи є визначення екологічного впливу на якість атмосферного повітря процесів благоустрою прибудинкових територій з наступною розробкою природоохоронних рекомендацій щодо зменшення екодеструктивного впливу на урбанізовані території.

МАТЕРІАЛ І РЕЗУЛЬТАТИ ДОСЛІДЖЕНЬ. Благоустрій населених пунктів являє собою комплекс робіт, які реалізуються на території населеного пункту з метою іiі раціонального використання, належного утримання та охорони, а також створення умов щодо захисту і відновлення сприятливого для людини довкілля [4]. Проведений аналіз стану сфери благоустрою населених пунктів дозволив встановити, що лише $22 \%$ населених пунктів мають затверджені програми 3 благоустрою, в містах цей показник становить - $88 \%$. Майже $40 \%$ населених пунктів мають затверджені плани заходів з благоустрою, одночасно з цим в містах цей показник становить $100 \%$. Правила благоустрою затверджено у $41 \%$ населених пунктах України, в містах цей показник становить $93 \%$. Лише $12 \%$ населених пунктів мають програми розвитку та збереження зелених 
зон населених пунктів, в містах цей показник становить $57 \%$. В $38 \%$ населених пунктах розроблені та затверджені схеми санітарної очистки, для міст цей показник становить $82 \%[5,6]$.

Як вже було зазначено, роботи з благоустрою території не входять до переліку робіт, які становлять підвищену небезпеку для навколишнього середовища та не потребують відповідного екологічного обгрунтування. Одночасно з цим вони проводяться на обмеженій території із застосуванням будівельної техніки у безпосередній близькості до житлових будинків, лікарень, шкіл та інших об'єктів, що суттєво підвищує рівень екологічної небезпеки при їх реалізації.

Аналіз негативних впливів на навколишнє середовище, джерелом яких $є$ проведення робіт з благоустрою території, дозволив виділити найбільш суттєві, до яких відносяться:

1) Забруднення атмосферного повітря шляхом:

- викиду відпрацьованих газів від працюючих на обмеженій площадці машин та при простоюванні транспорту при завантажувальних та розвантажувальних роботах з ввімкненими двигунами,

- утворення пилу при вантажнорозвантажувальних роботах та в місцях зберігання сипучих будівельних матеріалів;

2) Акустичного забруднення від дорожньобудівельних машин (ДБМ), обладнання та транспортних засобів;

3) Утворення відходів;

4) Зняття верхнього шару грунту та інтенсифікації ерозійних процесів [7].

Серед вказаних вище екодеструктивних впливів, на нашу думку найбільш доцільно розглядати вплив, який спричиняється на якість атмосферного повітря при роботі ДБМ.

Об'єктом дослідження $є$ типова для урбанізованих територій України прибудинкова територія житлового будинку житлового комплексу «Атлант», розташована у Новобаварському районі міста Харків за адресою Григоровське шосе, буд. 55 (рис. 1).

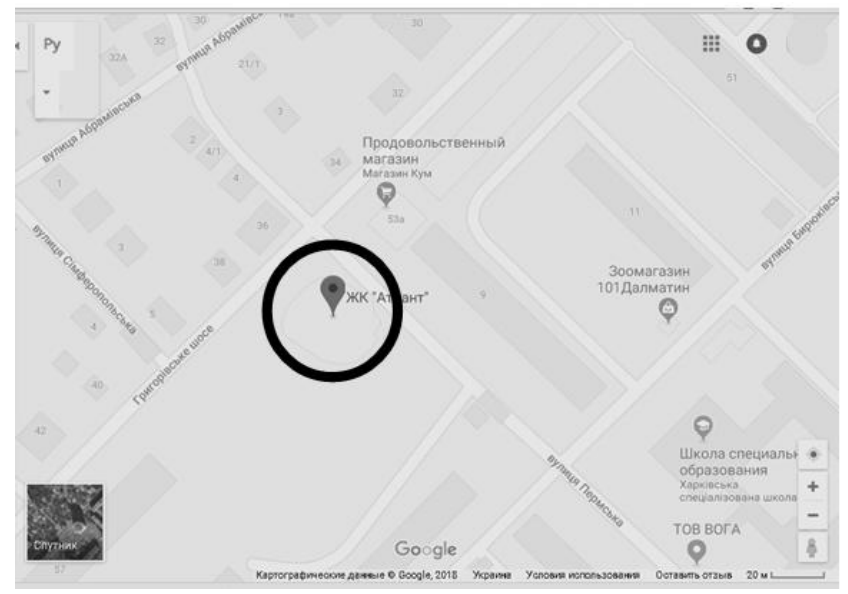

а) карта-схема розташування об'єкту дослідження

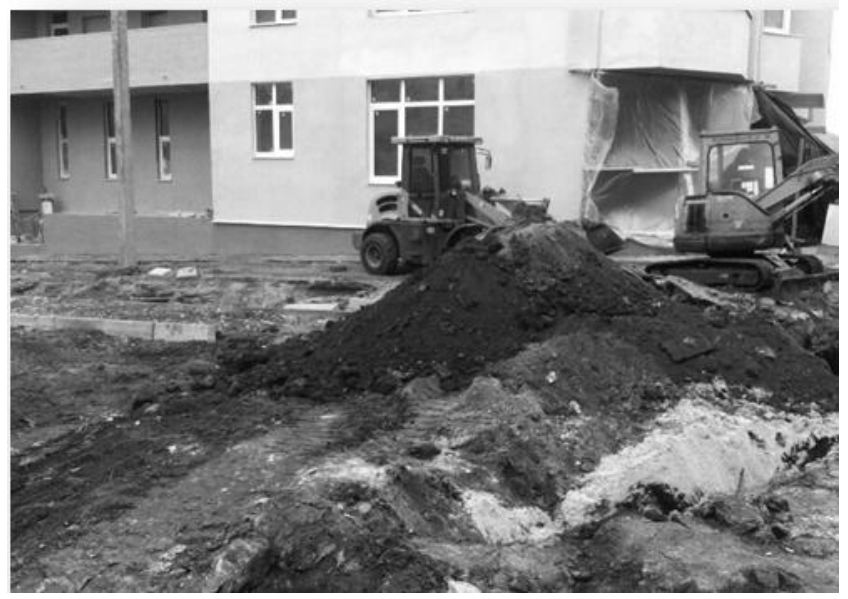

б) виконання робіт з благоустрою на об'єкті

Рисунок 1 - Характеристика об'єкту

У безпосередній близькості до об'єкту дослідження розташовані:

- Харківська спеціалізована школа I-III ступенів № $162-112$ м,

- дошкільний навчальний заклад ясла-садок №143 комбінованого типу Харківської міської ради $-65 \mathrm{M}$,

- дев'ятиповерховий житловий будинок - 43 м.

- дитячий спортивний майданчик - 25 м.

У весняно-літній період 2018 року комунальним підприємством КП «Харківспецбуд», яке виконує комплекс заходів 3 благоустрою та підтримання належного санітарного стану прибудинкових територій, вулиць, зупинок громадського транспорту, та інших об'єктів житлово-комунального та транспортного господарства у районах міста Харкова, надає послуги з ремонту, будівництва та експлуатації будівель та забезпечує належний рівень технічного стану житлового фонду, на досліджуваній території було проведено наступні роботи з благоустрою прибудинкової території:
- прокладка та монтаж інженерних комунікацій;

- пальові роботи;

- влаштування підпірних стінок, влаштування фундаментів;

- улаштування грунтових і піщано-гравійних основ, асфальтування автодоріг, тротуарів, майданчиків, установка бордюрного каменю та поребриків, улаштування фігурних елементів мощення, малих архітектурних форм, озеленення;

- монтаж і демонтаж залізобетонних конструкцій, монолітних фундаментів, фундаментних блоків, плит перекриття та покриття, стінових панелей, цегляна кладка;

- всі види зовнішніх і внутрішніх оздоблювальних робіт.

Під час даних робіт використовувалася наступні ДБМ на дизельному паливі:

- автогрейдер Дз-98 - використовуються для виконання землерийно-профілювальних робіт в дорожньому будівництві на грунтах I, II, III, IV категорій. Відповідає екологічному класу Євро 1; 
- екскаватор одноковшевий ЕТ-18 - багатоцільова землерийна машина, призначена для розробки котлованів, траншей, кар'єрів у грунтах I-IV категорій, завантаження і розвантаження сипучих матеріалів, розпушення скельних порід і мерзлих грунтів, а також для інших робіт в умовах промислового, міського, сільського, транспортного і меліоративного будівництва. Відповідає екологічному класу Свро 3;

- каток дорожній самохідний НAMM HD 75 зчленована спеціальна машина, оснащена гладкими вальцями (на які передається вібрація) і робочими місцями для двох операторів, призначена для виконання дорожньо-будівельних і дорожньо-ремонтних робіт, зокрема для укладання полотна і тротуарних плит, ущільнення основи для подальшого будівництва і створення паркувальних майданчиків. Відповідає екологічному класу Свро 3;

- асфальтоукладач Vogele-Super 1600 - агрегат універсального застосування призначений для укладання асфальтобетонного покриття на тротуарах, вулицях, прибудинкових територіях, многополосних автотрасах і швидкісних магістралях. Відповідає екологічному класу Свро 4

- КамАЗ 55111 - являє собою самоскид вантажопідйомністю до 20 т з колісною формулою $6 \times 4$ i вантажною платформою заднього розвантаження, призначений для перевезення по дорогах будь-якого покриття повного спектру сипучих вантажів і будівельних матеріалів. Відповідає екологічному класу Свро 2;

- кран КС55713-1К - кран автомобільний вантажопідйомністю 25 т призначений для виконання навантажувально-розвантажувальних і будівельномонтажних робіт на розосереджених об'єктах. Відповідає екологічному класу Свро 4;

- вилковий навантажувач BALKANCAR ДВ 1792 - спеціальний складський наземний транспорт, призначений для підняття, переміщення, розвантаження, навантаження, складування (штабелювання) палетів, піддонів та інших різних вантажів за допо- могою вил або інших робочих пристосувань (навісного обладнання). Відповідає екологічному класу Євро 2 [8].

Саме для цих ДМБ, як основного джерела забруднення атмосферного повітря при проведення робіт 3 благоустрою прибудинкових територій, була проведена інвентаризація викидів та оцінено їх розсіювання.

Згідно [9] розрахунок ведеться для ДБМ, які мають в якості силового приводу двигун з запалюванням від жаття (дизель) для наступних забруднюючих речовин:

- монооксид вуглецю (CO);

- оксиди азоту в перерахунку на $\mathrm{NO}_{2}\left(\mathrm{NO}_{\mathrm{x}}\right)$;

- аміак $\left(\mathrm{NH}_{3}\right)$;

- сірчистий ангідрид $\left(\mathrm{SO}_{2}\right)$;

- тверді частки (РМ).

За одиницю часу при розрахунку викидів забруднюючих речовин від ДБМ приймається машиногодина (маш.-год.).

Викид $i$-ї забруднюючої речовини від ДБМ $j$-го типу за деталізованою розрахунковою схемою у г/м·год. розраховується за формулою:

$$
M_{i j}=N e_{M_{i j}} \cdot K u_{j} \cdot\left(g_{i j}+\frac{g_{i j} \cdot K_{c}}{100}\right) \cdot K_{\text {д }},
$$

де $N e_{M j}$ - паспортне значення номінальної потужності двигуна ДБМ $j$-го типу, кВт (табл. 1);

$K u_{j}-$ коефіцієнт використання потужності двигуна (табл. 1);

$g_{i j}$ - середнє значення викиду $i$-ї забруднюючої речовини на одиницю потужності двигуна ДБМ $j$-го типу (базовий питомий викид), г/(кВт·год.) (табл. 1);

$K_{c}$ - коефіцієнт урахування віку машини (табл. 2);

$K_{\partial}-$ коефіцієнт, який враховує вид робочого процесу двигуна (табл. 2).

Таблиця 1 - Характеристика ДБМ, які використовувалися на об'єкті

\begin{tabular}{|c|c|c|c|c|c|c|c|c|}
\hline \multirow{2}{*}{ Назва ДБМ } & \multirow{2}{*}{$\begin{array}{c}\mathrm{Ne}_{\mathrm{Mj}}, \\
\mathrm{KBT}\end{array}$} & \multirow{2}{*}{$K u_{j}$} & \multicolumn{6}{|c|}{$g_{i j,}$ кг/(кВт.год.) } \\
\hline & & & $\mathrm{NH}_{3}$ & $\mathrm{NO}_{\mathrm{x}}$ & $\mathrm{CH}_{4}$ & $\mathrm{CO}$ & PM & $\mathrm{SO}_{2}$ \\
\hline Автогрейдер Дз-98 & 173 & 0,5 & 0,002 & 18,00 & 0,05 & 14,00 & 1,10 & 0,404 \\
\hline Екскаватор одноковшевий ЕТ-18 & 90,5 & 0,65 & 0,002 & 18,00 & 0,05 & 14,00 & 1,23 & 0,413 \\
\hline Каток дорожній самохідний HAMM HD 75 & 86 & 0,7 & 0,002 & 14,40 & 0,05 & 3,49 & 1,23 & 0,413 \\
\hline Укладальник асфальтобетону Vogele-Super 1600 & 100 & 0,5 & 0,002 & 14,40 & 0,05 & 3,49 & 1,23 & 0,413 \\
\hline КамА3 55111 & 162 & 0,6 & 0,002 & 18,00 & 0,05 & 14,00 & 1,10 & 0,404 \\
\hline Кран КС-55713-1К & 191 & 0,6 & 0,002 & 18,00 & 0,05 & 14,00 & 1,10 & 0,404 \\
\hline Вилковий навантажувач BALKANCAR ДВ 1792 & 52 & 0,75 & 0,002 & 14,40 & 0,05 & 5,06 & 1,51 & 0,421 \\
\hline
\end{tabular}

Таблиця 2 - Значення довідкових коефіцієнтів

\begin{tabular}{|c|c|c|c|c|c|c|}
\hline \multirow{2}{*}{ Коефіцієнт } & \multicolumn{5}{|c|}{ Забруднююча речовина } \\
\cline { 2 - 7 } & $\mathrm{NH}_{3}$ & $\mathrm{NO}_{\mathrm{x}}$ & $\mathrm{CH}_{4}$ & $\mathrm{CO}$ & $\mathrm{PM}$ & $\mathrm{SO}_{2}$ \\
\hline$K_{c}$ & 0 & 0 & 1,5 & 1,5 & 3 & 1 \\
\hline$K_{\partial}$ & 1 & 1,0 & 0,8 & 0,8 & 0,9 & 0,95 \\
\hline
\end{tabular}

Результати розрахунку забруднення атмосферного повітря від ДБМ забруднюючими речовинами наведено у табл. 3. Для оцінювання рівня впливу робіт з благоустрою досліджуваної прибудинкової території на якість атмосферного повітря було виконано розрахунок розсіювання викидів від ДБМ із застосуванням моделі Гаусового розподілу домішок в атмосфері на невеликих висотах згідно [10]. 
Таблиця 3 - Результати розрахунку викидів у атмосферного повітря від ДБМ на об’єкті дослідження

\begin{tabular}{|l|c|c|c|c|c|}
\hline \multirow{2}{*}{ Назва ДБМ } & \multicolumn{5}{c|}{ Викид в атмосферне повітря, г/м·с } \\
\cline { 2 - 6 } & $\mathrm{NH}_{3}$ & $\mathrm{NO}_{\mathbf{x}}$ & $\mathrm{CO}$ & $\mathrm{PM}$ & $\mathrm{SO}_{2}$ \\
\hline Автогрейдер Дз-98 & 0,2 & 1245,6 & 316,1 & 78,4 & 33,5 \\
\hline Екскаватор одноковшевий х ЕT-18 & 0,1 & 847,1 & 215,0 & 59,6 & 23,3 \\
\hline Коток дорожній самохідний HAMM HD 75 & 0,1 & 693,5 & 81,6 & 61,0 & 23,9 \\
\hline Укладальник асфальтобетону Vogele Super 1600 & 0,1 & 576,0 & 52,8 & 50,7 & 19,8 \\
\hline КамА3 55111 & 0,2 & 1399,7 & 355,2 & 88,1 & 37,7 \\
\hline Кран КС-55713-1К-1 & 0,2 & 1650,2 & 418,8 & 103,9 & 44,4 \\
\hline Вилочковий навантажувач ВALKANCAR ДВ 1792 & 0,1 & 449,3 & 72,2 & 48,53 & 15,8 \\
\hline Сумарний викид & 1,0 & 6861,4 & 1511,7 & 490,23 & 198,4 \\
\hline
\end{tabular}

Розрахунок розсіювання досліджуваних забруднюючих речовин та визначення концентрацій на розрахункових відстанях виконувався згідно формули:

$$
C=\frac{2 M_{i j}}{\sqrt{2 \pi} \cdot \delta \cdot V \cdot \sin \varphi}+F,
$$

де $C$ - концентрація даного забруднювача в атмосферному повітрі, мг/ $\mathrm{M}^{3}$;

$M_{i}-$ сумарний викид $i$-ї забруднюючої речовини від досліджуваних ДБМ, г/м·год.;

$\delta$ - стандартне відхилення Гаусового розсіювання в вертикальному напрямку, м (табл. 4);

$V$ - швидкість повітря, переважаючого у розрахунковий місяць літнього періоду, м/с;

$\varphi$ - кут, який складається напрямком вітру з переважаючим напрямом руху ДБМ; $\Gamma / \mathrm{M}^{3}$.

$F$ - фонова концентрація забруднення повітря,

Таблиця 4 - Стандартне відхилення Гаусового розсіювання в вертикальному напрямку

\begin{tabular}{|c|c|c|c|c|c|c|c|c|c|}
\hline \multirow{2}{*}{$\begin{array}{l}\text { Сонячна } \\
\text { радіація }\end{array}$} & \multicolumn{9}{|c|}{$\begin{array}{c}\text { Значення стандартного відхилення } \\
\text { Гаусового розсіювання в вертикальному } \\
\text { напрямку, м }\end{array}$} \\
\hline & 10 & 20 & 40 & 60 & 80 & 100 & 150 & 200 & 250 \\
\hline Сильна & 2 & 4 & 6 & 8 & 10 & 13 & 19 & 24 & 30 \\
\hline Слабка & 1 & 2 & 4 & 6 & 8 & 10 & 14 & 18 & 22 \\
\hline
\end{tabular}

Розрахунок розсіювання виконувався для липня місяця 2018 року за сильної сонячної радіації на основі даних Харківського регіонального центру 3 гідрометеорології щодо фонових концентрацій забруднюючих речовин у атмосферному повітрі міста Харкова, а також середньої швидкості та напряму вітру [11] на відстанях, що відповідає відстаням до суб'єктів впливу дослідження. Результати розрахунку представлено у табл. 5. У дослідженні встановлено суттєве перевищення значень фактичних концентрацій за всіма забруднюючими речовинами у атмосферному повітрі на визначених відстанях над середньодобовими значеннями граничнодопустимих концентрацій відповідних речовин (табл. 6), що вказує на суттєвий рівень впливу робіт з благоустрою прибудинкових територій на якість атмосферного повітря.
Таблиця 5 - Результати розрахунку розсіювання забруднюючих речовин від ДБМ при проведенні робіт з благоустрою досліджуваної прибудинкової території

\begin{tabular}{|c|c|c|c|c|}
\hline \multirow{2}{*}{$\begin{array}{c}\text { Забруднююча } \\
\text { речовина }\end{array}$} & \multicolumn{4}{|c|}{$\begin{array}{c}\text { Концентрації забруднюючих речо- } \\
\text { вин на визначених відстанях, мг/м }\end{array}$} \\
\cline { 2 - 5 } & $25 \mathrm{~m}$ & $43 \mathrm{~m}$ & $65 \mathrm{~m}$ & $112 \mathrm{M}$ \\
\hline $\mathrm{NH}_{3}$ & 0,11 & 0,104 & 0,102 & 0,098 \\
\hline $\mathrm{NO}_{\mathrm{x},}$ & 0,211 & 0,164 & 0,148 & 0,127 \\
\hline $\mathrm{CO}$ & 4,85 & 3,81 & 3,47 & 2,99 \\
\hline $\mathrm{PM}$ & 1,53 & 1,19 & 1,08 & 0,92 \\
\hline $\mathrm{SO}_{2}$ & 0,11 & 0,104 & 0,102 & 0,098 \\
\hline
\end{tabular}

Таблиця 6 - Перевищення нормативних показників забруднюючих речовин у атмосферному повітрі району дослідження

\begin{tabular}{|c|c|c|c|c|c|}
\hline \multirow{2}{*}{$\begin{array}{c}\text { Забруд- } \\
\text { нююча } \\
\text { речовина }\end{array}$} & \multirow{2}{*}{$\begin{array}{c}\text { ГДК } \\
\text { або } \\
\text { ОБРВ, } \\
\mathrm{M \Gamma}^{3} \mathrm{M}^{3}\end{array}$} & \multicolumn{4}{|c|}{ Перевищення, рази } \\
\hline & & $25 \mathrm{M}$ & $43 \mathrm{~m}$ & $65 \mathrm{~m}$ & $112 \mathrm{M}$ \\
\hline $\mathrm{NH}_{3}$ & 0,04 & 2,75 & 2,60 & 2,55 & 2,45 \\
\hline $\mathrm{NO}_{\mathrm{x}}$ & 0,04 & 5,28 & 4,10 & 3,70 & 3,18 \\
\hline $\mathrm{CO}$ & 3,0 & 1,60 & 1,27 & 1,16 & 0,99 \\
\hline PM & 0,15 & 10,20 & 7,93 & 7,20 & 6,13 \\
\hline $\mathrm{SO}_{2}$ & 0,05 & 2,20 & 2,08 & 2,04 & 1,96 \\
\hline
\end{tabular}

Аналіз отриманих даних свідчить про те, що на досліджуваних відстанях від об'єкту є перевищення граничнодопустимих концентрацій за всіма вказаними забруднюючими речовинами, незважаючи на тенденцію до зменшення рівня концентрації з відстанню у середньому на $30 \%$. Виключення становить лише моноксид вуглецю, який досягає нормативного значення на відстані розташування Харківської спеціалізованої школи I-III ступенів № 162. Максимальне перевищення на всіх відстанях спостерігається для речовини третього класу небезпечності сажі, яка пріоритетно викидається при роботі дорожньо-будівельних машин на дизельному паливі.

Результати оцінки екологічного впливу при проведенні робіт з благоустрою досліджуваної типової прибудинкової території за показником забруднення атмосферного повітря при роботі дорожньобудівельних машин показав переважно недопустимий його рівень, що вимагає розробки заходів спрямованих на відповідне зниження їх концентрацій.

Отже, в результаті аналізу досвіду зменшення екодеструктивного впливу при роботі дорожньобудівельних машин вважаємо за доцільне запропо- 
нувати наступні типові заходи, що можуть бути застосовані на подібних об'єктах для попередження погіршення екологічної ситуації.

Основні заходи по скороченню забруднення атмосферного повітря при виконанні будівельних та ремонтних робіт в першу чергу повинні бути спрямовані на зменшення викидів відпрацьованих газів. Обсяг викидів і зміст в них токсичних речовин залежать від кількості споживаного палива і технічного стану двигуна, головним чином, системи живлення. Несправність або неврегульованість двигунів збільшує обсяг викидів і їх токсичність в $1,2-1,4$ рази $[12,13]$.

Контроль за станом атмосфери повинен виконуватися на постійній основі згідно нормативних документів:

- «Державні санітарні правила охорони атмосферного повітря населених місць (від забруднення хімічними та біологічними речовинами)» - поза межами будівельного майданчика (смуга відведення);

- ДСТУ 7748-2015 «Безпека праці. Біологічна безпека. Загальні вимоги» - в робочій зоні.

- ДСТУ 4276: 2004 «Система стандартів у Галузі охорони навколишнього природного середовища та раціонального використання ресурсів. Атмосфера. Норми і методи вимірювання дімності і відпрацьованих газів автомобілів 3 дизелями або газодизелями» - вимоги до будівельних і дорожніх машин.

Контроль за дотриманням норм і вимог повинен проводитися при прийманні зразків встановлених серій машин, підтверджуватися у процесі сертифікації (в тому числі для машин закордонного виробництва) і експлуатації.

Для дизельних двигунів димність відпрацьованих газів не повинна перевищувати: $40 \%$ - в режимі вільного прискорення, $15 \%$ - при максимальній частоті обертання. Антідимні добавки в дизельне паливо можуть знижувати димність викидів на $40-60 \%$. Токсичність відпрацьованих газів дизельних двигунів мінімальна при $60-70 \%$ робочому навантаженні. Для зменшення забруднення атмосфери слід передбачати перехід дорожніх машин на газове паливо, а стаціонарного обладнання - на електропривод.

Оскільки, у роботі було встановлено значний рівень екодеструктивного впливу від машин, устаткування та транспортних засобів, які працюють на обмеженій площадці території населених пунктів, то вище наведені заходи (із коригуванням відповідно до конкретних умов) необхідно у обов'язковому порядку включати до проектів благоустрою прибудинкових територій, що може значно поліпшити ступінь екологічного благополуччя урбанізованих територій.

ВИСНОВКИ. Визначено ступінь екологічного впливу процесів благоустрою прибудинкових територій для типового об'єкту, встановлено його суттєвий рівень за показниками забруднення атмосферного повітря при роботі дорожньо-будівельних машин. Розроблено природоохоронні рекомендацій щодо зменшення техногенного навантаження на атмосферне повітря урбанізованої території при проведення подібних робіт.

\section{ЛІТЕРАТУРА}

1. Бахарєв В. С. Структура інформаційно-аналітичної системи муніципального моніторингу якості атмосферного повітря. Вісник КрНУ імені Михайла Остроградського. Кременчук, 2017. Вип. 3 (104). Частина 1. С. 85-92.

2. Желновач Г. М. Оцінка ступеня техногенного навантаження на придорожній простір (на прикладі обходу м. Лубни). Вісник КрНУ імені Михайла Остроградського. Кременчук, 2013. Вип. 5 (82). С. 156-159.

3. Желновач А. Н. Анализ внедрения природоохранных требований при оценке влияния автомобильной дороги на окружающую среду. Вестник Харьковского национального автомобильно-дорожного университета. Харьков, 2010. Вып. 48. С. 29-32.

4. Ігнатенко О. П. Формування державної політики у сфері благоустрою населених пунктів. Державне управління: теорія та практика: електрон. друк. фахове вид. 2014. Вип. 1. С. 89-95. URL: http://nbuv.gov.ua/UJRN/Dutp_2014_1_12 (дата звернення: 21.02.2019).

5. Parikh P., Parikh H., McRobie A. The role of infrastructure in improving human settlements. Proceedings of the Institution of Civil Engineers Urban Design and Planning. 2013. Vol. 166. No. 2. pp. 101-118. URL: http://discovery.ucl.ac.uk/1363775/1/Parikh_udap\%252 E10\%252E00038.pdf (дата звернення: 01.03.2019).

6. Ігнатенко О. П. Аналіз стану та проблем в сфері благоустрою населених пунктів. Державне управління: удосконалення та розвиток: електрон. друк. фахове вид. 2014. Вип. 6. URL: http://www.dy.nayka.com.ua/?op=1\&z=734 (дата звернення: 21.09.2019).

7. Рішення «Про встановлення Правил благоустрою території міста Харкова». - Харків : Харківська міська рада, від 16 лист. 2011 р., № 504/11. URL: http://old.city.kharkov.ua/ru/document/pravila-

blagoustroyu-teritoriyi-mista-harkova-2401.html (дата звернення 21.09.2018).

8. Босняк М. Г. Вантажні автомобільні перевезення: навч. посіб. Київ: Видавничий Дім «Слово», 2010. 408 c.

9. Ерошенко Я. Б., Самхарадзе К. К. Мониторинг загрязнения воздушного бассейна строительной техникой. Инновации в науке. Новосибирск, 2017. Вип. 8 (69). С. 7-10.

10. Ерошенко Я. Б., Самхарадзе К. К. Компьютерный анализ рассеивания выбросов в атмосферный воздух дорожно-строительной техникой. Научные ведомости БелГУ. Белгород. 2018. Том 45 (1). C. 111-117.

11. Екологічний паспорт Харківської області, 2017. URL: https://kharkivoda.gov.ua/oblasnaderzhavna-administratsiya/struktura-

administratsiyi/strukturni-pidrozdili/486/2736/88326?sv (дата звернення: 28.02.2019).

12. NSW Cleaner Vehicles and Fuels Strategy. Sydney South, NSW: Department of Environment and Climate Change, 2008. 32 p.

13. Parikh P., McRobie A. Engineering as a tool for improving human habitat. International Journal of Management and Decision Making. Geneva, 2009. Vol. 10 (3/4). pp. 270-281. 


\section{G. Zhelnovach}

\section{ENVIRONMENTAL IMPACT ASSESSMENT DURING THE WORK ON HOUSE TERRITORY ACCOMPLISHMENT}

Kharkiv National Automobile and Highway University

vul. Yaroslava Mudrogo, 25, Kharkiv, 61002, Ukraine. E-mail: zhelnovach84@gmail.com

Purpose. The article aims to determine environmental impact on the quality of atmospheric air in the processes of improvement of house territories with the subsequent development of environmental recommendations for reducing eco-destructive effects on urban areas as well as to determine sources and consequences of environmental impact work on accomplishment of house territories; assess atmospheric air pollution during work on accomplishment of the house territory of the research object; development of environmental recommendations. Methodology. The results were obtained by the method of calculations using the following normative documents "Settlement instruction (methodology) on inventory of pollutant emissions by road construction machines into atmospheric air" and "Recommendations for accounting of requirements for OCS in the design of highways and bridge transitions". Results. Demonstrate a significant level of eco-destructive impact of road-building machines (identified as the main source of environmental impact on atmospheric air), since there are significant exceedances of the maximum permissible concentrations for all substances under study. Originality. For the first time, the level of environmental impact of work on beautification of house territories on atmospheric air has been determined. This activity becomes especially relevant in the context of the fact that the work on accomplishment of the house territory is not included in the list of works that constitute an increased danger to the environment and do not require appropriate environmental justification. At the same time, they are carried out on a limited territory with the use of construction equipment in the immediate vicinity of residential buildings, hospitals, schools and other facilities, which significantly increases the level of environmental hazard during their implementation. Practical value. The level of influence of the research works and environmental measures to reduce it were determined. References 13, 6 tables, 1 figure.

Key words: environmental impact, atmospheric air, beautification, house territory, road building machines.

\section{REFERENCES}

1. Bakharev, V. S. (2017) "Structure of the municipal atmospheric air quality monitoring information and analytical system", Transactions of Kremenchuk Mykhailo Ostrohradskyi National University, vol. 3, no. 104 , pp. 85-92.

2. Zhelnovach, G. M. (2013), "Assessment of technogenic loading on roadside area (the case of lubny bypass road)", Transactions of Kremenchuk Mykhailo Ostrohradskyi National University, vol. 5, no. 82, pp. 156-159.

3. Zhelnovach, G. M. (2010), "Analysis of introduction of nature protection requirements at estimation of highway influence on nature environment", Bulletin of Kharkiv National Automobile and Highway University, no. 48, pp. 29-32.

4. Ignatenko, O. P. (2014), "Formation of state policy in the field of improvement of human settlements", Public Administration: Theory and Practice, vol. 1., pp. 89-95, available at: http://nbuv.gov.ua/UJRN/Dutp_2014_1_12 (accessed February 21, 2019).

5. Parikh, P., Parikh, H., McRobie, A. (2013), "The role of infrastructure in improving human settlements", Proceedings of the Institution of Civil Engineers - Urban Design and Planning, vol. 166, no. 2, pp. 101-118, available

at: http://discovery.ucl.ac.uk/1363775/1/Parikh_udap\%252 E10\%252E00038.pdf (accessed March 01, 2019).

6. Ihnatenko, O. P. (2014), "Analysis of the situation and problems in the area of improvement of settlements", Public Administration: Improvement and Development, no. $6, \quad$ available at http://www.dy.nayka.com.ua/?op=1\&z=734 (accessed September 21, 2018).
7. Decision "On the establishment of Rules of Kharkiv city territory beautification" (2007), available at http://old.city.kharkov.ua/ru/document/pravilablagoustroyu-teritoriyi-mista-harkova-2401.html (accessed September 21, 2018).

8. Bosniak, M. G. (2010), Vantazhni avtomobilni perevezennia [Road freight transportations], Vydavnychyi Dim «Slovo», Kyiv, Ukraine.

9. Eroshenko, Ya. B., Samharadze, K. K. (2017), "Monitoring of air pollution by construction equipment", Innovations in science, vol. 8, no. 69, pp. 7-10.

10. Eroshenko, Ya. B., Samharadze, K. K. (2018), "Computer analysis of the dispersion of air emissions by road construction equipment", Belgorod State University Scientific Bulletin, vol. 45, no. 1, pp. 111-117.

11. "Environmental passport of Kharkiv region" (2017), available at https://kharkivoda.gov.ua/oblasnaderzhavna-administratsiya/struktura-

administratsiyi/strukturni-pidrozdili/486/2736/88326?sv (accessed February 28, 2019).

12. "NSW Cleaner Vehicles and Fuels Strategy" (2008), Sydney South, NSW: Department of Environment and Climate Change, $32 \mathrm{p}$.

13. Parikh, P., McRobie, A. (2009), "Engineering as a tool for improving human habitat", International Journal of Management and Decision Making, vol. 10 no. $3 / 4$, pp. $270-281$. 